\title{
Artificial covering on trap nests improves the colonization of trap-nesting wasps
}

\author{
Hisatomo Taki ${ }^{1}$, Peter G. Kevan ${ }^{1}$, Blandina F. Viana ${ }^{2}$, Fabiana O. Silva ${ }^{3}$ \& Matthias Buck ${ }^{1}$ \\ 1 Department of Environmental Biology, University of Guelph, Guelph, Canada \\ 2 Instituto de Biologia, Universidade Federal da Bahia, Salvador, Brazil \\ 3 Licenciatura em Ciências Biológicas, Faculdades Jorge Amado, Salvador, Brazil, and Bacharelado em Ciências Biológicas, Faculdade de Tecnolo- \\ gia e Ciências, Salvador, Brazil
}

\section{Keywords}

aculeate, bee, Carolinian forest, cavity

nesting, trap-nesting wasps

\begin{abstract}
Correspondence
Hisatomo Taki (corresponding author), Department of Forest Entomology, Forestry and Forest Products Research Institute, 1 Matsunosato, Tsukuba, Ibaraki 305-8687, Japan. E-mail: htaki@affrc.go.jp
\end{abstract}

Received: January 15, 2007; accepted: May 22, 2007.

doi: 10.1111/j.1439-0418.2007.01237.x

\begin{abstract}
To evaluate the role that a trap-nest cover might have on sampling methodologies, the abundance of each species of trap-nesting Hymenoptera and the parasitism rate in a Canadian forest were compared between artificially covered and uncovered traps. Of trap tubes exposed at eight forest sites in six trap-nest boxes, 531 trap tubes were occupied and 1216 individuals of 12 wasp species of four predatory families, Vespidae (Eumeninae), Crabronidae, Sphecidae and Pompilidae emerged over 2 years, and no bee species were found. Results indicated that artificial covering led to a significant increase in the number of nested tubes of Ancistrocerus adiabatus, Ancistrocerus antilope, Ancistrocerus campestris and Auplopus mellipes, and significant effects of covering were not found for the other species. No significant difference in the overall parasitism rate between covered and uncovered traps was noted. These suggested that the covering technique could provide more opportunities for some wasp species to colonize trap nests.
\end{abstract}

\section{Introduction}

The trap-nest technique has been used in many fields of research to study cavity-nesting bees and wasps (Hym., Aculeata). Trap nests have the potential to increase recognized biodiversity through the discovery of new species (Griswold 2001) and to be used in conservation and restoration (Gaston et al. 2005). Trap nests have recently been suggested as a valuable tool in environmental assessment of various ecosystems (Tscharntke et al. 1998; Steffan-Dewenter 2002; Tylianakis et al. 2005, 2006a,b, 2007; Taki et al. 2007). Trap-nesting species could also provide contributions to agriculture and forestry by augmenting populations of pollinators and biological control agents (Harris 1994; Wearing and Harris 1999, 2005; Klein et al. 2003, 2006).

Protective cover on trap nests may offer protection from wind, rain and sunlight, thus leading to somewhat stabilized humidity and temperature (Frankie et al. 1988). Although Taki et al. (2004) showed a positive effect (i.e. more nest-plugged tubes) of artificial covering on trap nests, the identification of insects in the tubes were not made. This study leads to a further discussion of the work and focuses on the emerged and identified insect species.

The main objective of this study was to investigate the effect of artificial covering on trap nests, and in particular to see if the covering technique would result in more bees and wasps to accept the artificial nests. Based on the identified species, two specific questions are addressed in this study: (1) Is the abundance of trap-nesting Hymenoptera species collected from covered traps greater than uncovered ones? (2) Does cover affect parasitism rates of the trap-nesting species in both the covered and uncovered traps? 


\section{Materials and Methods}

Study sites and trap nests

The study was carried out in Norfolk County of southern Ontario, Canada $\left(42^{\circ} 37^{\prime}-42^{\circ} 48^{\prime} \mathrm{N}, 80^{\circ} 25^{\prime}-\right.$ $\left.80^{\circ} 39^{\prime} \mathrm{W}\right)$, where many plant species with high conservation priority occur (Allen et al. 1990; Argus 1992). The county is located in the area with warm and dry climate called Carolinian Forest Zone, which is part of the temperate deciduous forest region that extends south into the United States. Over 70 native species of trees, including oaks, maples, hickories, ashes, dogwoods, black walnut, sassafras, tulip tree and chestnut have been reported (Waldron 2003).

Eight sites in the forest, all at least $4 \mathrm{~km}$ apart from each other, were selected. Site selection was made using randomized numbers for the eight points representing their latitudes and longitudes along with ArcView (version 3.3; ESRI, Redlands, CA, USA) in the laboratory. All of the selected points were also confirmed by using global positioning system (GPS) (Garmin International, Olathe, KS, USA) in the field before the actual experiments started. The data of forest distributions produced using aerial photography (1:30000 and 1:50 000) were obtained from the Ontario Base Map Series in 2003 (Ontario Ministry of Natural Resources, Peterborough, Ontario, Canada).

At each site, six trap-nest boxes were attached to trees $1-1.5 \mathrm{~m}$ from the ground at the corners of a hexagonal array $50 \mathrm{~m}$ from the randomly selected centre point. The six nest boxes at each site were divided randomly into the two treatments: three covered and three uncovered. Artificial coverings were provided by pieces of burlap that extended 10$15 \mathrm{~cm}$ beyond the entrance and sides of the nest boxes (fig. 1). The compass orientation of each box was randomly selected. Each trap-nest box was constructed from a $2-1$ milk carton $(9.5 \times 9.5 \times 16.5 \mathrm{~cm})$ with a polystyrene entrance piece plug that held 36 paper tubes, nine each of 3-, 5-, 7- and 9-mm internal diameter $\times 15 \mathrm{~cm}$ depth (Custom Paper Tubes Inc., Cleveland, $\mathrm{OH}, \mathrm{USA}$; fig. 1), which provides a range of opportunities for hymenopteran species to make their nests (Potts et al. 2005).

Collection of tubes plugged with soil or plant material, indicating nests occupied by aculeate Hymenoptera (Krombein 1967), was made five times from 25 June to 20 August in 2003, while a full canopy was present. Removed tubes were immediately replaced with new, empty tubes of the same size. All

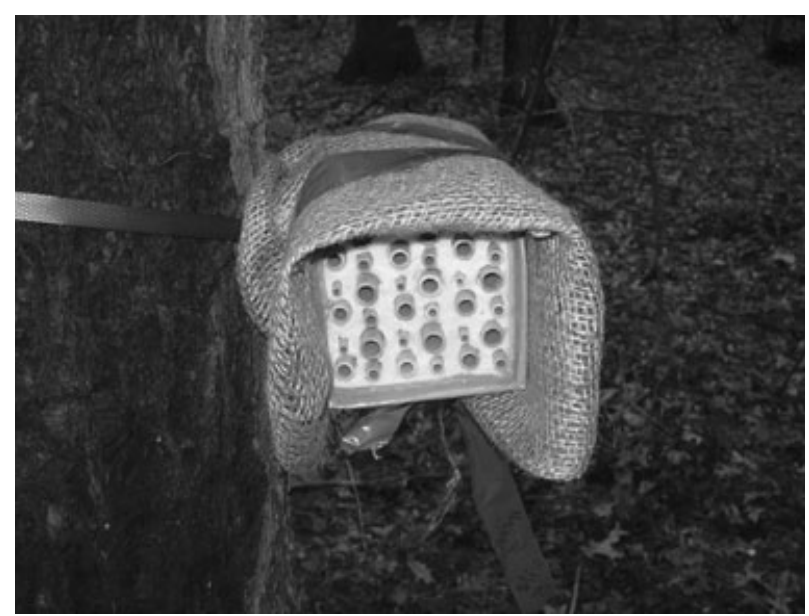

Fig. 1 Nest box covered by burlap with 36 tubes of four different diameters $(3,5,7$ and $9 \mathrm{~mm})$, set in the Carolinian forest zone of southern Ontario, Canada $\left(42^{\circ} 37^{\prime}-42^{\circ} 48^{\prime} \mathrm{N}, 80^{\circ} 25^{\prime}-80^{\circ} 39^{\prime} \mathrm{W}\right)$.

the plugged tubes from the trap-nest boxes at each of the sites were collected individually, labelled and brought into the laboratory at the University of Guelph.

Each tube was then placed in a plastic tube (12 mm internal diameter $\times 17 \mathrm{~cm}$ depth $\times 2 \mathrm{~mm}$ wall thickness) with the ends covered by pieces of metal mesh. All these filled plastic tubes were kept outside on the campus of University of Guelph, Guelph, Ontario, Canada $\left(42^{\circ} 31^{\prime} \mathrm{N}, 80^{\circ} 13^{\prime} \mathrm{W}\right)$ to allow for the insects' development under more or less natural conditions and to await emergences of the adults. The tubes were checked for any emerging insects over 2 years, at least three times a week from 25 June to 30 November in 2003 and at least once per week from 1 May to 30 November in 2004. All insects found from the tubes were pinned and labelled. Specimens were identified by M. Buck using the references (Bohart and Kimsey 1982; Shewell 1987). Vouchers are deposited in Department of Environmental Biology, University of Guelph.

\section{Data analysis}

The randomized complete block design (RCBD) was used to evaluate the effects of the covered and uncovered treatments, where the five sampling times were added, the eight sites were treated as blocks and the three trap-nest boxes per treatment at each site were pooled. Type I error rate $(\alpha)$ was set at 0.05 for all the following analyses. 
First, using the RCBD, the number of occupied tubes from trap nests was compared between the covered and uncovered treatments for each trapnesting species. Generalized linear mixed models (GLMMs) were conducted for individual trap-nesting species. These analyses were performed by $\mathrm{R}$ version 2.4.1 (R Development Core Team 2006) and lme4 R package (Bates and Sarkar 2007) with blocks (sites) as a random factor, treatments (cover) as a fixed factor and Poisson distribution as the error distribution. The effects of treatments were tested by model comparisons (Faraway 2006), between models with only a random (site) factor and models with both a treatment (cover) factor and the random factor.

Secondly, the comparison of the overall parasitism rates between covered and uncovered treatments was made, using the RCBD. This analysis was performed by the R's GLMM with sites as a random factor and cover as a fixed factor and binominal distribution as the error distribution (Crawley 2005). The effect of treatments was tested by comparing a model with only a random (site) factor and a model with both a treatment (cover) factor and the random factor. The number of tubes was used for this analysis, instead of the number of insects, because it was assumed that multiple individuals would emerge from a single host and a single individual would emerge from multiple hosts in some parasites (Krombein 1967).

\section{Results}

A total of 612 tubes with emerged insects, including both trap-nesting and parasite species, were observed. Of the total, 531 tubes (1216 emerged individuals) of 12 species of trap-nesting wasps of four families, Vespidae (Eumeninae), Crabronidae, Sphecidae and Pompilidae, were identified over 2 years, and no bee species were found.

The statistical analyses indicated that there were significantly more tubes of Ancistrocerus adiabatus, Ancistrocerus antilope, Ancistrocerus campestris and Auplopus mellipes found from covered traps than from uncovered ones, but no significant differences between traps were found for the other wasp species $(\mathrm{P}>0.05)$ (table 1).

Two species of hymenopteran parasites, Chrysis coerulans and Chrysis nitidula (Chrysididae), and one species of dipteran parasite, Amobia sp. (Sarcophagidae), emerged from the trap tubes. The mean rate of parasitism from covered trap nests was $24.59 \%$ and that from uncovered trap nests was $22.06 \%$. No significant difference between the rates was indicated $\left(\chi^{2}=0.006, P=0.9398\right)$.

\section{Discussion}

We did not find the evidence that artificial cover on trap nests affected the wasp species Euodynerus

Table 1 Twelve wasp species collected from trap-nests in the Carolinian forest zone of southern Ontario, Canada

\begin{tabular}{|c|c|c|c|c|c|c|}
\hline \multirow[b]{2}{*}{ Insect } & \multicolumn{2}{|c|}{ No. individual specimens } & \multicolumn{4}{|l|}{ No. tubes } \\
\hline & Covered & Uncovered & Covered & Uncovered & $\chi^{2}$ & P-value \\
\hline \multicolumn{7}{|l|}{ Vespidae: Eumeninae } \\
\hline Ancistrocerus adiabatus (Saussure)* & $12.38 \pm 6.74$ & $2.25 \pm 1.26$ & $3.25 \pm 1.33$ & $0.75 \pm 0.31$ & 13.48 & 0.0002 \\
\hline Ancistrocerus antilope (Panzer)* & $60.88 \pm 22.17$ & $33.16 \pm 12.35$ & $28.13 \pm 10.19$ & $17.5 \pm 6.17$ & 19.98 & $<0.0001$ \\
\hline Ancistrocerus campestris (Saussure)* & $1.13 \pm 1.13$ & 0 & $0.50 \pm 0.50$ & 0 & 5.54 & 0.0186 \\
\hline Euodynerus foraminatus (Saussure) & 0 & $0.63 \pm 0.63$ & 0 & $0.13 \pm 0.13$ & 1.39 & 0.2391 \\
\hline Symmorphus canadensis (Saussure) & $3.25 \pm 1.92$ & $3.63 \pm 1.74$ & $1.63 \pm 1.10$ & $1.75 \pm 1.10$ & 0.04 & 0.8485 \\
\hline Symmorphus cristatus (Saussure) & $2.00 \pm 1.51$ & $5.63 \pm 4.10$ & $0.63 \pm 0.50$ & $1.50 \pm 1.05$ & 2.97 & 0.0849 \\
\hline \multicolumn{7}{|l|}{ Crabronidae } \\
\hline Trypoxylon frigidum Smith & $0.75 \pm 0.75$ & $0.13 \pm 0.13$ & $0.13 \pm 0.13$ & $0.13 \pm 0.13$ & 0.00 & 0.9762 \\
\hline Trypoxylon lactitarse Saussure & 0 & $1.00 \pm 1.00$ & 0 & $0.25 \pm 0.25$ & 2.75 & 0.0975 \\
\hline \multicolumn{7}{|l|}{ Sphecidae } \\
\hline Isodontia mexicana (Saussure) & $0.13 \pm 0.13$ & 0 & $0.13 \pm 0.13$ & 0 & 1.39 & 0.2390 \\
\hline \multicolumn{7}{|l|}{ Pompilidae } \\
\hline Auplopus mellipes (Say)* & $8.50 \pm 2.38$ & $3.50 \pm 1.07$ & $4.25 \pm 1.10$ & $1.63 \pm 0.50$ & 9.72 & 0.0018 \\
\hline Dipogon sayi sayi Banks & $6.38 \pm 2.60$ & $6.50 \pm 2.03$ & $2.00 \pm 0.82$ & $2.00 \pm 0.60$ & 0.00 & 0.9952 \\
\hline Dipogon papago anomalus Dreisbach & $0.25 \pm 0.25$ & 0 & $0.13 \pm 0.13$ & 0 & 1.39 & 0.2390 \\
\hline
\end{tabular}

The mean numbers of individuals and tubes with their standard errors per site for each of the 12 species from covered $(n=8)$ and uncovered $(n=8)$ trap-nest boxes and the statistical results are shown.

*Significant differences between covered and uncovered treatments were indicated in A. adiabatus, A. antilope, A. campestris and A. mellipes. 
foraminatus, Symmorphus canadensis, Symmorphus cristatus, Trypoxylon frigidum, Trypoxylon lactitarse, Isodontia mexicana, Dipogon sayi sayi and Dipogon papago anomalus. However, it is notable that the use of an artificial cover is an effective way to improve trapnest settings as a sampling method for $A$. adiabatus, $A$. antilope, $A$. campestris and $A$. mellipes.

In this study, there were significantly and substantially more tubes occupied by these four species found from covered traps than from uncovered ones. Covers might offer protection from wind, rain and sunlight leading to stabilized humidity and temperature. Although our study was made in a forested ecosystem, varieties of trap systems could provide shelter from these environmental factors for other trap-nesting hymenopteran species, including leafcutter bees, in agricultural ecosystems. However, the factors of microclimates were not measured in our experiment, so further experiments and observations are needed to conclude what factors are indeed affecting those species to enhance the colonization of trap systems.

The artificial cover in this study represents a physical addition to the basic trap nests. An alternative of the cover might be to use shorter tubes that are recessed into the trap-nest boxes made of milk carton. The lower side of the tubes could be cut back to protect the tubes from wind, rain and sunlight.

Among the four species, A. adiabatus and $A$. antilope have been reported as common wasps in northeastern North America (Godfrey and Hilton 1983). These species are predators hunting various species of lepidopteran larvae, and has been studied as one of the potential biological control agents against spruce budworms Choristoneura fumiferana (Lep., Tortricidae) (Jennings and Houseweart 1984; Collins and Jennings 1987). Setting trap nests provides possible nesting sites for Ancistrocerus (Wearing and Harris 1999), and the artificial cover on the trap nests substantially enhances colonization by the Ancistrocerus species as the results indicate. Therefore, the use of trap nests and the technique of covering could potentially contribute to the value in biological control of lepidopteran pests by the Ancistrocerus species.

Parasites did not respond to the different trap designs. The overall parasitism rate was not significantly different between covered and uncovered treatments, indicating that the artificial covering did not seem to prevent the attacks of the trap-nesting wasp parasites. The collected parasites $C$. coerulans, $C$. nitidula and Amobia are known from a broad range of host species. Krombein (1967) reported that both cuckoo wasps, C. coerulans and C. nitidula, parasitized various species of Eumeninae in the genera Ancistrocerus, Euodynerus, Stenodynerus and Symmorphus. Amobia spp. attack Ancistrocerus, Euodynerus, Monobia, Symmorphus and Pachodynerus (Vespidae, Eumeninae), Trypoxylon (Crabronidae), Isodontia and Sceliphron (Sphecidae) (Krombein 1967). Many of the trapnesting wasps found in the study are included in those listed potential host species.

\section{Acknowledgements}

We thank Long Point Conservation Authority, F. Saul, J. DeCloet and V. Sinnave for access to the study sites, C. Sheffield and S. Rigby for providing trap-nests, and V. MacPhail, M. Horn, A. Morse, G. Umphrey and J. Trevors for discussion. In addition, we greatly thank Y. Yamaura for statistic consultant, C. Connell and Q. Shirk-Luckett for GIS support and J. Boone, G. Huber and E. Tanaka for their assistance with the field sampling. This research was supported by a scholarship from the Rotary Foundation to H. Taki and a grant from the Natural Sciences and Engineering Research Council of Canada to P. Kevan.

\section{References}

Allen GM, Eagles PFJ, Price SD, 1990. Conserving Carolinian Canada. University of Waterloo Press, Waterloo.

Argus GW, 1992. The phytogeography of rare vascular plants in Ontario and its bearing on plant conservation. Can. J. Bot. 70, 469-490.

Bates D, Sarkar D, 2007. Ime4: Linear mixed-effects models using S4 classes. R package version 0.9975-12, URL http://CRAN.R-project.org/.

Bohart RM, Kimsey LS, 1982. A synopsis of the Chrysididae in America north of Mexico. Mem. Am. Entomol. Inst. 33, 1-266.

Collins JA, Jennings DT, 1987. Spruce budworm and other lepidopterous prey of eumedid wasps Hymenoptera Eumenidae in spruce-fir forests of Main USA. Great Lakes Entomol. 20, 127-134.

Crawley MJ, 2005. Statistics: an introduction using R. John Wiley, New York.

Faraway JJ, 2006. Extending the linear model with R. Chapman and Hall, Boca Raton, FL.

Frankie GW, Vinson SB, Newman LE, Barthell JF, 1988. Nest site and habitat preference of Centris bees in the Costa Rican dry forest. Biotropica 20, 301310.

Gaston KJ, Smith RM, Thompson K, Warren PH, 2005. Urban domestic gardens (II): Experimental tests of methods for increasing biodiversity. Biodivers. Conserv. 14, 395-413. 
Godfrey S, Hilton DFJ, 1983. Nesting biology of solitary wasps and bees in the eastern townships region, Quebec. Can. Field Nat. 97, 1-8.

Griswold T, 2001. Two new species of trap-nesting Anthidiini (Hymenoptera: Megachilidae) from Sri Lanka. Proc. Entomol. Soc. Wash. 103, 269-273.

Harris AC, 1994. Ancistrocerus gazella (Hymenoptera: Vespoidea: Eumenidae): a potentially useful biological control agent for leafrollers Plantortix octo, P. excessana, Ctenopseustis obliqua, C. herana, and Epiphyas postvittana (Lepidoptera: Tortricidae) in New Zealand. New Zeal. J. Crop Hort. 22, 235-238.

Jennings DT, Houseweart MW, 1984. Predation by eumenid wasps Hymenoptera Eumenidae on spruce budworm Choristoneura fumiferana Lepidoptera Tortricidae and other lepidopterous larvae in spruce fir forest of Main. Ann. Entomol. Soc. Am. 77, 39-45.

Klein AM, Steffan-Dewenter I, Tscharntke T, 2003. Pollination of Coffea canephora in relation to local and regional agroforestry management. J. Appl. Ecol. 40, 837-845.

Klein AM, Steffan-Dewenter I, Tscharntke T, 2006. Rain forest promotes trophic interactions and diversity of trap-nesting hymenoptera in adjacent agroforestry. J. Anim. Ecol. 75, 315-323.

Krombein KV, 1967. Trap-nesting wasps and bees: life histories, nests and associates. Smithsonian Institution Press, Washington DC.

Potts SG, Kevan PG, Boone JW, 2005. Conservation in pollination: Collecting, surveying and monitoring. In: Practical pollination biology. Ed by Dafni A, Kevan PG, Husband BC, Enviroquest, Cambridge, 401-434.

R Development Core Team, 2006. R: a language and environment for statistical computing. $\mathrm{R}$ foundation for statistical computing, Vienna.

Shewell GE, 1987. Sarcophagidae. In: Manual of Nearctic Diptera, Vol. 2. Ed. by McAlpine JF, Peterson BV, Shewell GE, Teskey HJ, Vockeroth JR, Wood DM, Research Branch, Agriculture Canada, Monograph 28, Ottawa, 1159-1186.

Steffan-Dewenter I, 2002. Landscape context affects trap-nesting bees, wasps, and their natural enemies. Ecol. Entomol. 27, 631-637.
Taki H, Boone JW, Viana BF, Silva FO, Kevan PG, Sheffield CS, 2004. Effect of shading on trap nest utilization by hole-nesting aculeate Hymenoptera. Can. Entomol. $136,889-891$.

Taki H, Viana BF, Kevan PG, Silva FO, Buck M, 2008. Does forest loss affect the communities of trap-nesting wasps (Hymenoptera: Aculeata) in forests? Landscape vs. local habitat conditions. J. of Insect Conserv. 12, 15-21.

Tscharntke T, Gathmann A, Steffan-Dwenter I, 1998. Bioindication using trap-nesting wasps and their natural enemies: community structure and interactions. J. Appl. Ecol. 35, 708-719.

Tylianakis JM, Klein AM, Tscharntke T, 2005. Spatiotemporal variation in the diversity of hymenoptera across a tropical habitat gradient. Ecology 86, 3296-3302.

Tylianakis JM, Klein AM, Lozada T, Tscharntke T, 2006 a. Spatial scale of observation affects alpha, beta and gamma diversity of cavity-nesting bees and wasps across a tropical land-use gradient. J. Biogeogr. 33, 1295-1304.

Tylianakis JM, Tscharntke T, Klein AM, 2006b. Diversity, ecosystem function, and stability of parasitoid host interactions across a tropical habitat gradient. Ecology 87, 3047-3057.

Tylianakis JM, Tscharntke T, Lewis OT, 2007. Habitat modification alters the structure of tropical host-parasitoid food webs. Nature 445, 202-205.

Waldron G, 2003. Trees of the Carolinian forest: a guide to species, their ecology and uses. Boston Mills Press, Toronto.

Wearing CH, Harris AC, 1999. Evaluation of the predatory wasp, Ancistrocerus gazella, for biological control of leafrollers in Otago fruit crops: I. Prey composition, nest structure and wasp productivity from artificial nests. Biocontrol Sci. Technol. 9, 315-325.

Wearing CH, Harris AC, 2005. Evaluation of the predatory wasp, Ancistrocerus gazella, for biological control of leafrollers in Otago fruit crops. II. Wasp phenology and seasonal changes in prey composition. Biocontrol Sci. Techn. 15, 281-298. 